\title{
Visualization of midwifery education in 109 countries on a world map: Secondary analysis of the data from the International Confederation of Midwives (ICM)
}

\author{
International Committee of the Japan Society of Midwifery Education (2017 2018), \\ Emi TAHARA-SASAGAWA*1, Yasue OTA*2, Masayo MATSUZAKI*3, \\ Yoko SHIMPUKU*4, and Tokiko OISHI*5
}

\begin{abstract}
Purpose

This study aimed to acquire knowledge regarding the differences of training courses and educational institutions providing midwifery education through visualization by analyzing the related data from the International Confederation of Midwives (ICM).

\section{Methods}

Secondary analysis was performed using data from 109 countries out of 113 countries included in the ICM data available on their website. The following midwifery education-related items were plotted on the world map: (1) academic degree at the time of graduation, (2) midwifery education program, and (3) number of midwifery graduates per educational institution. For regional comparison, data were divided into six regions according to the World Health Organization (WHO) classification.

Results

Regarding academic degree at the time of graduation, from among 87 countries, diplomas and bachelor's and master's degrees were confirmed for 47 (54.0\%), 65 (74.7\%), and $35(40.2 \%)$ countries, respectively (multiple answers). Regarding the midwifery education program, from among 94 countries, 76 (80.9\%) had a direct-entry education program and 57 countries $(60.6 \%)$ had a post-nursing midwifery education program. For the number of midwifery graduates per educational institution, the data for 80 countries were divided into quartiles. The median of midwifery graduate per institution was 22.5 .
\end{abstract}

\section{Conclusion}

An international comparison was made through visualization using ICM data, and this study identified a wide range of training course and educational institutions of midwifery education. Direct-entry programs were more adopted than post-nursing midwifery programs. In the countries in Africa, where maternal mortality ratio and total fertility rete were high, a diploma course was more likely to be provided, and the number of graduates per institution tended to be higher.

Key words: midwife, education, International Confederation of Midwives (ICM), World Health Organization (WHO)

\footnotetext{
${ }^{* 1}$ The University of Tokyo, Graduate School of Medicine

*2 Juntendo University, Graduate School of Health Care and Nursing

*3 Osaka University, Graduate School of Medicine

${ }^{* 4}$ Hiroshima University, Graduate School of Biomedical and Health Sciences

${ }^{* 5}$ Takasaki University of Health and Welfare, Graduate School of Nursing
} 


\section{Introduction}

The International Confederation of Midwives (ICM) is a professional association of midwives comprising 131 member associations across 113 countries. The ICM aims to improve maternal and child health through evidencebased, highly qualified midwifery care. The Essential Competencies for Midwifery Practice, 2018 UPDATE defines the competencies of midwives as "the minimum set of knowledge, skills and professional behaviors required by an individual to use the designation of midwife" (ICM, 2019). Under this qualification, midwifery education programs have been developed in each country. As education is one of the most important ICM activities, most ICM member countries may be regarded as those that provide midwifery education within the national education system.

The ICM presents the midwife map on its official website in three categories: health indicators, midwifery education, and midwifery regulation. When users place the cursor over a specific country on the map, the indicators for that country appear on the screen. Moreover, the data sourced from ICM member associations are available as a Microsoft Excel spreadsheet (ICM, 2018). Among the 32 indicators of ICM data, 13 indicators were related to midwifery education (e.g., number of educational institutions, type of institution [whether public or private], type of educational program [whether directentry or post-nursing midwifery program], months of study required to qualify, and the number of midwifery graduates per year).

This study aimed to acquire knowledge regarding the differences of training courses and educational institutions providing midwifery education by visualizing the aforementioned ICM data. We focused on the following three items that could grasp the diversity of midwifery education by using the five indicators of ICM data, either alone or in combination: (1) academic degree at the time of graduation, (2) midwifery education program, and (3) number of midwifery graduates per educational institution.

According to the Picture Superiority Effect theory, presentations that use pictures are more likely to be recalled and recognized than those that use words alone
(Hockley, 2008). This theory has been broadly applied to demonstrate the geographical differences and regional or inter-regional gaps related to the achievement of global issues, such as the Millennium Development Goals or other health outcomes. Therefore, we believe that mapping may be a useful tool for fostering a better understanding, even for those who are less involved in international health and midwifery. The maps used in this study were prepared as part of an internal report in 2018 by the International Committee of the Japan Society of Midwifery Education to provide a brief introduction to global midwifery education for the association members. For the publication, we translated the maps into English.

\section{Methods}

We performed secondary analysis using the existing data available from the ICM, which contains information on 113 countries and regions. First, to create a map for the academic degree at the time of graduation, countries were classified according to the type and combination of academic degrees provided: (1) diploma only, (2) bachelor's degree only, (3) master's degree only, (4) diploma and bachelor's degree, (5) bachelor's and master's degrees, (6) diploma, bachelor's, and master's degrees, and (7) diploma and master's degree. These seven categories were presented on a color-coded map by classification of the academic degree. Moreover, countries with missing data and those of non-ICM members were distinguished and color-coded on the map.

Second, to show the global distribution of direct-entry programs that train students to become midwives without first becoming a nurse, and post-nursing midwifery programs, countries were classified as follows: (1) both direct-entry and post-nursing midwifery programs, (2) direct-entry program only, and (3) post-nursing midwifery program only. In addition, the duration of the training course required qualifying for both the direct-entry program and the post-nursing midwifery program was obtained. In this paper, the integrated nurse-midwifery program was categorized into the post-nursing midwifery program based on the ICM classification (ICM, 2013).

Lastly, the number of midwifery graduates per educational institution was established for each country, and 
then a descriptive analysis was performed to identify the quartile points.

For the sake of regional comparison, data were divided into six regions according to the World Health Organization (WHO) classification: African Region (AFRO), Eastern Mediterranean Region (EMRO), South-East Asia Region (SEARO), Western Pacific Region (WPRO), PanAmerican Region (PAHO), and European Region (EURO).

Valid data, which included outcome measures in an observation, were analyzed using IBM SPSS Statistics for Windows version 26 (IBM Corp., Armonk, NY, USA). Midwifery maps were created using mapping software (i.e., business mapping and cartography add-ins in MS Excel., FreeFormat. Co., Ltd., Japan).

This study involved secondary data analysis. According to the Ethical Guidelines for Medical and Health Research Involving Human Subjects issued by the Japanese Ministry of Health, Labour and Welfare, ethical approval is not required for research using information of which the value has already been academically established, and which is widely utilized in research and is generally available.

\section{Results}

The ICM data used for this study were last updated on November 18, 2018. Of 113 countries, we included 109 but excluded four countries-one country that was registered twice (duplicate registration) and three regions (specifically, Puntland, Somaliland, and Hong Kong: nonmember countries of the United Nations) that did not correspond with the mapping software.

\section{Academic degree at the time of graduation from midwifery education}

Of the 109 countries, the academic degrees of 87 were analyzed using valid data $(79.8 \%)$. The academic degrees, classified into seven types, were demonstrated on a map (Figure 1).

There were 15 countries (17.2\%) wherein students had only a (1) diploma. Normally, a diploma is provided by training institutions and vocational schools. Moreover, there were 17 countries (19.5\%) wherein students had only a (2) bachelor's degree, and six countries (6.9\%) wherein they had only a (3) master's degree. The most common was a combination of (4) diploma and bachelor's degree, found in 20 countries (23.0\%), followed by that of (5) both bachelor's and master's degrees in 17 countries (19.5\%). The combination of (6) diploma and bachelor's and master's degrees was found in 11 countries (12.6\%). The combination of (7) diploma and master's degree was found in only one country (1.1\%), Portugal.

Upon analyzing the 87 countries with valid data (multiple answers), diplomas and bachelor's degrees were confirmed in $47(54.0 \%)$ and $65(74.7 \%)$ countries, respectively. Master's degrees were confirmed in 35 countries (40.2\%), including 17 countries from the EURO and 10 countries from the AFRO.

Among the 15 countries that only provide a diploma program, most were from the AFRO and PAHO regions - five and four countries, respectively. The six countries that only provide a master's degree program are Kenya from the AFRO, Ecuador from the PAHO, and four countries from the EURO; all of the institutions in these countries were public schools. Interestingly, institutions in Ecuador and two of the EURO countries (France and Poland) provided direct-entry programs, whereas institutions in Kenya and the rest of the EURO (Norway and Sweden) offered post-nursing midwifery programs.

\section{Midwifery education program}

The type of midwifery program and duration (months) of training required to qualify were analyzed using valid data from 94 countries $(86.2 \%)$. Data about the presence and absence of direct-entry programs as well as post-nursing midwifery programs in the countries were analyzed, with the results plotted on the map (Figure 2). There were 39 $(41.5 \%)$ countries with both direct-entry programs and post-nursing midwifery programs, 37 countries (39.4\%) with only direct-entry programs, and 18 countries (19.1\%) had only post-nursing midwifery programs.

Overall, direct-entry programs were confirmed in 76 countries $(80.9 \%)$ and post-nursing midwifery programs were confirmed in 57 countries $(60.6 \%)$. When the data from 94 countries were divided into the six regions, direct-entry programs were adopted more than the postnursing programs, except in the WPRO (data not shown).

For direct-entry programs, the mean number of months of training was 37.1. The EURO had the longest mean 


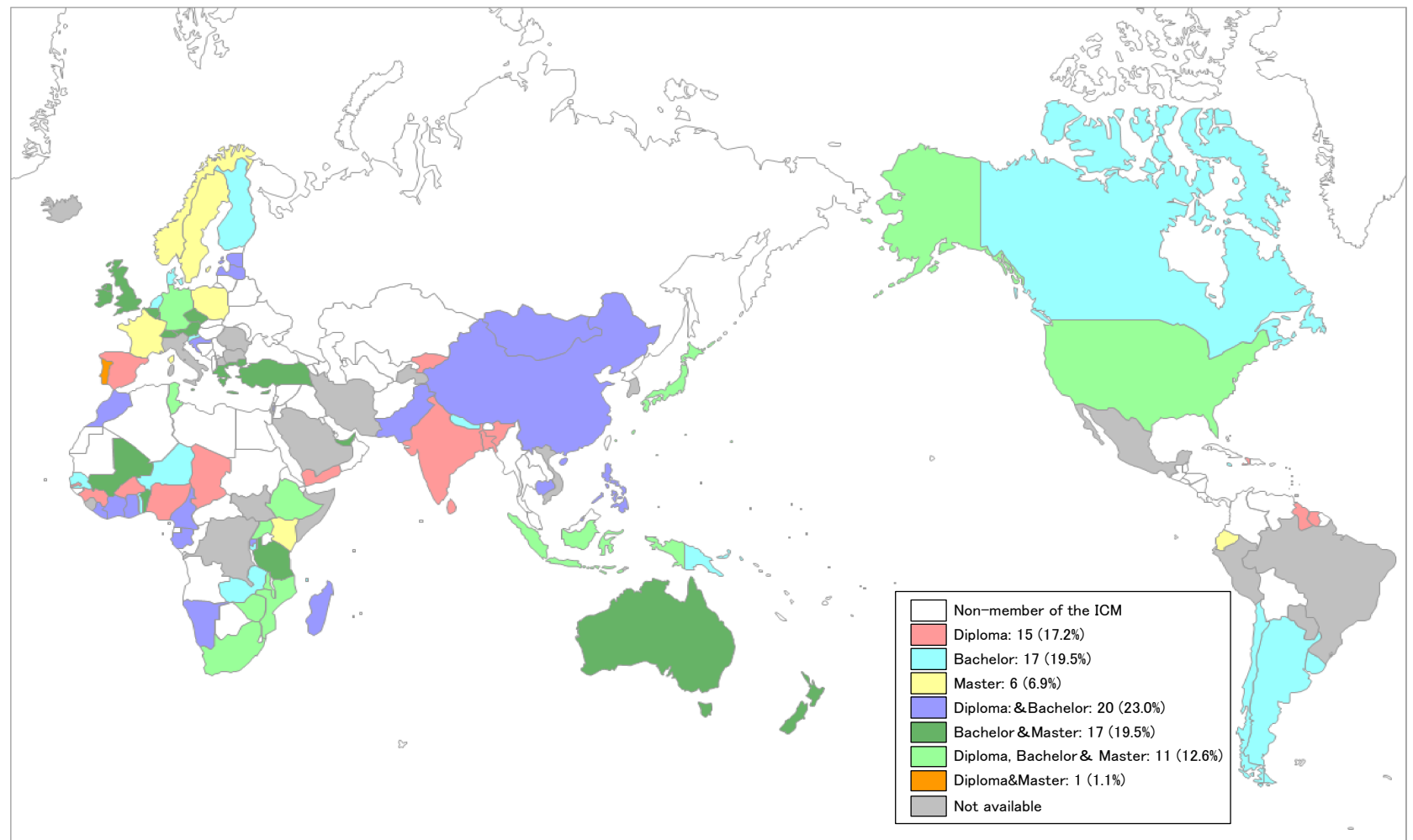

Figure 1 Midwifery map demonstrating the academic degree at the time of graduation from midwifery education, involving data from 87 of ICM members' countries

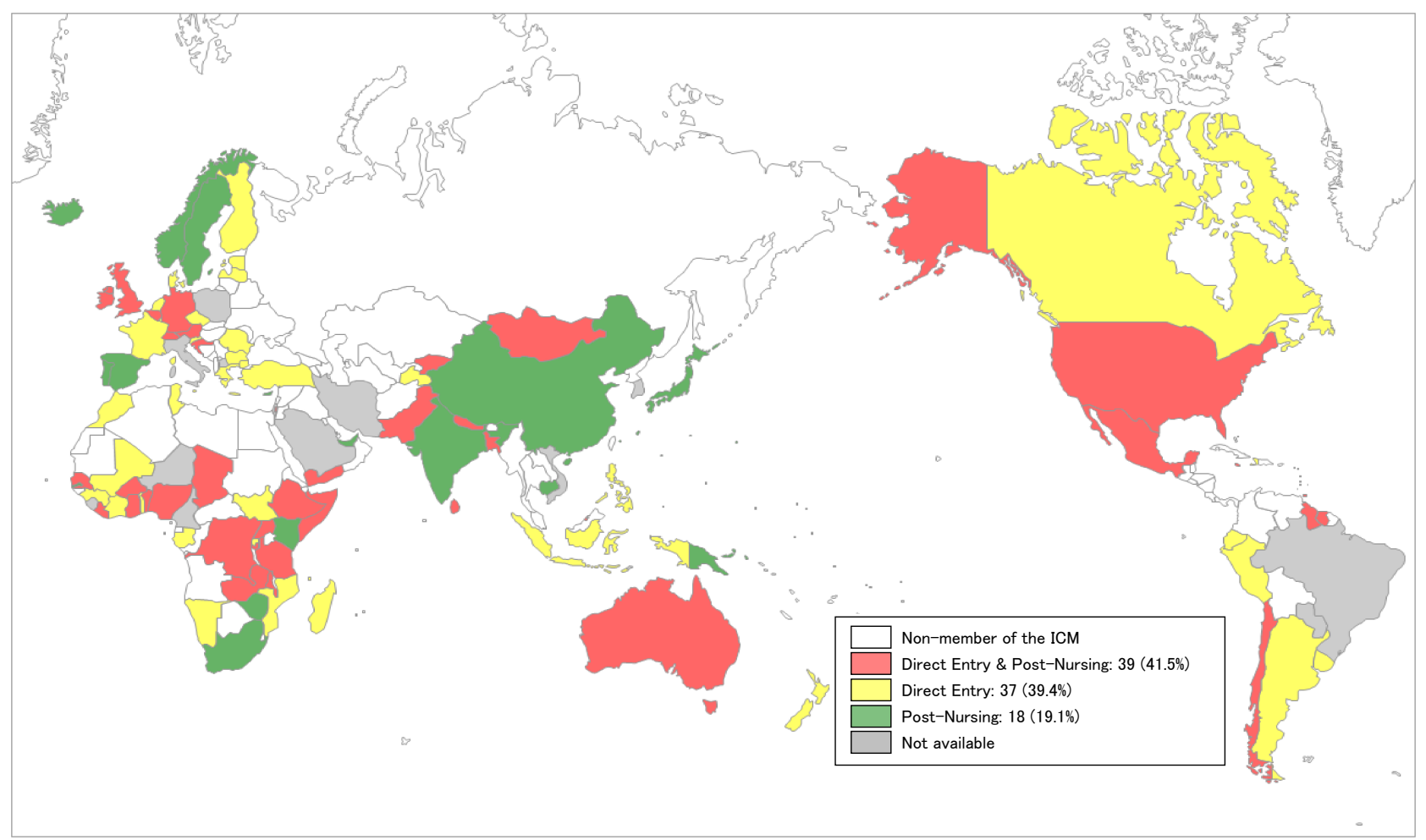

Figure 2 Midwifery map demonstrating type of midwifery education program involving data from 94 of ICM members' countries 


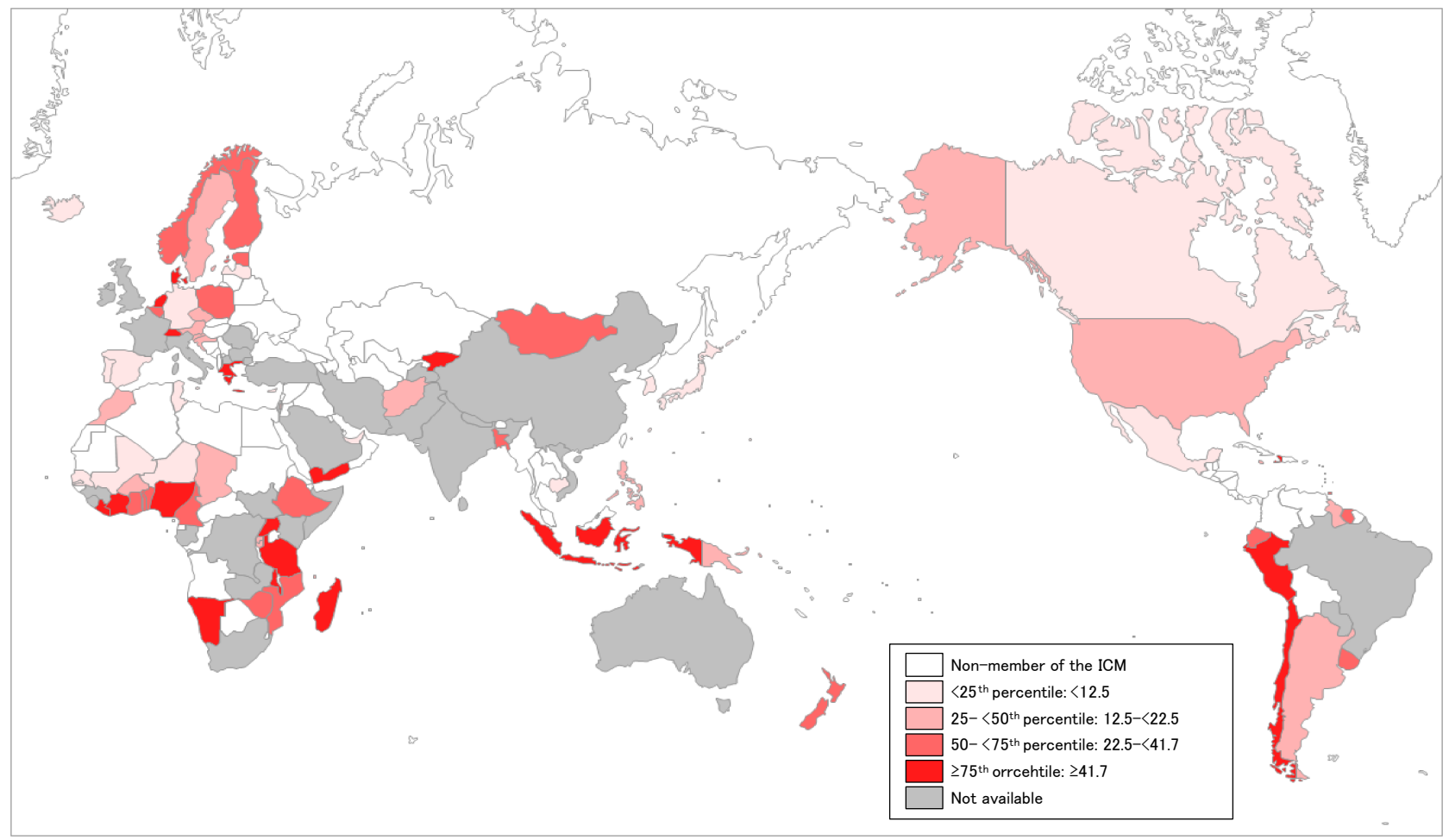

Figure 3 Midwifery map demonstrating the average number of midwifery graduates per educational institution, involving data from 80 of ICM members' countries

duration (43.5 months), and the SEARO had the shortest mean duration (27.0 months). A total of 20 countries, including 10 countries from the AFRO, did not meet the ICM minimum standard of three years (36 months) for a direct-entry program (ICM, 2013). Likewise, for postnursing midwifery programs, the mean number of months of training was 19.4. The SEARO had the longest mean duration (22.5 months) and the WPRO had the shortest mean duration (10.0 months). A total of 19 countries, including 7 countries from the AFRO and 6 countries from the WPRO, did not meet the ICM minimum standard of 18 months for a post-nursing midwifery program. A twelve-month post-nursing midwifery training program was most common in countries that did not meet the duration standard, such as Australia, Japan, and Cambodia.

\section{Number of midwifery graduates per educational institution}

The number of midwifery graduates per educational institution was analyzed using valid data from 80 countries $(73.4 \%)$, and data were divided into quartiles (Figure 3). The median of midwifery graduates per in- stitution was 22.5. Countries classified as being in the first quartile had 0-12.5 graduates, and the third quartile had at least 41.7 graduates per institution, on average.

When data were further divided into the six regions, in the first quartile group (smaller number of midwifery graduates per institution), there were slightly more countries from the EURO than from other regions (7 out of 18 countries). In contrast, in the fourth quartile group (larger number of graduates per institution), there were slightly more countries from the AFRO than from other regions (9 out of 22 countries).

\section{Discussion}

\section{Academic degree at the time of graduation from midwifery education}

The number of graduate midwifery schools have increased gradually due to the increased need for midwifery educators to train midwives who provide safe, high quality, and efficient health services (WHO, 2013; WHO, 2015). Regarding academic degrees in midwifery education, which were classified into seven types, most coun- 
tries trained midwives through a combination of diploma and bachelor's degree courses.

Focusing on the 15 countries that provided only a diploma, several countries had an extremely high maternal mortality ratio (MMR). In particular, the mean MMR of five countries from the AFRO in this group was 685.2 (min 371 - max 856). Furthermore, the mean total fertility rate (TFR) among these AFRO countries was 5.26 (min 5.0 - $\max 6.2)$.

In 2014, a report on the State of the World's Midwifery was published by three international organizations, including the ICM (UNFPA, et al. 2014). This report analyzed the availability of skilled birth attendants (SBAs) in 75 low-and middle-income countries, and found that availability was limited to only $42 \%$, thus suggesting a need for more midwifery personnel. In light of this finding, in countries with high rates of birth and maternal mortality, human resource development of midwives through the minimum amount of training that can be provided is suggested.

On the other hand, this study identified six countries that only provide a master's degree program. All institutions were public schools, but half of them only provided a direct-entry program and the other half only provided a post-nursing midwifery program, representing the diversity of midwifery education among six countries.

Among the 35 countries providing master's degrees, whether in combination with another qualification or otherwise, there were 17 countries from the EURO and 10 countries from the AFRO. Some countries still have high rates of incomplete compulsory education, especially for women, due to economic burdens or social beliefs regarding gender (UNICEF, 2019). Taking into account the lower proportion of male midwives in the world (in 37 countries where male midwives were present, median proportion of male midwives was 0.6\%.) (Sannomiya, et al. 2019), it is likely that the opportunity to acquire a master's degree may be limited to only a few people in these countries. Considering the differences in the completion rate of primary education or upper secondary education in the AFRO and EURO, there might be significant differences in the roles of and expectations from postgraduate midwives between the two regions.

\section{Midwifery education program}

This study revealed that a relatively high percentage $(80.9 \%)$ of ICM member countries have introduced a direct-entry program (Figure 3). A previous study focusing on 54 countries that compared midwifery education in 2011 and 2014 reported that the number of countries that had a direct-entry program increased from $35 \%$ to $83 \%$ over that period (Castro Lopes, et al. 2016). The percentage of direct-entry programs in 2014, referred to in the previous report (83\%), was similar to that found in this study $(80.9 \%)$. This increase might be related to the fact that the proportion of deliveries attended by skilled health personnel (doctor, nurse or midwife) was selected as one of the indicators of MDGs goal 5 to achieve the reduction of the MMR (UNFPA, et al. 2014).

A review of midwifery education in Australia (Ohara, et al. 2015) showed that midwives trained in a directentry program tend to provide midwifery care for low-risk pregnant women, whereas midwives trained through post-nursing midwifery education through master's degree tend to provide care for high-risk pregnant women in tertiary-level medical facilities. In all likelihood, directentry programs may have been widely adopted to increase the maternal and child health status at primary level rather than tertiary-level facilities, considering the low availability of SBAs, especially in low- and middleincome countries.

The study period for direct-entry programs and postnursing programs was 37.2 months (3.1 years) and 19.4 months (1.6 years), respectively, which met the ICM standards. However, of the 94 countries included in this analysis, 30 were from AFRO and 29 from EURO. It is possible that the duration of training in the EURO, lasting 43 months, had an influence on the mean length of training in all countries.

\section{Average number of midwifery graduates per educational institution}

Of the 80 countries analyzed, the mean number of graduates trained per educational institution was 22.5. In this analysis, 26 AFRO countries were included, and the proportion of AFRO countries was gradually increased from the first quartile group, having smaller numbers of graduates, toward the fourth quartile group, having larger 
numbers of graduates per institution. Focusing on the fourth quartile group, the mean of MMR and TFR of nine African countries in this group was very high -518 (min 265 - $\max 814$ ) and 4.7 ( $\min 5.0$ - $\max 6.2$ ), respectively. Similar to the analysis on academic degrees, probably, due to the urgent need to train more midwives in a short period, a larger number of students per institution were educated in this group.

\section{Implications}

According to the Global Standards for Midwifery Education, fostering qualified midwives who can provide evidence-based quality healthcare for women, newborns, and families is regarded as an important pillar of the ICM (ICM, 2013). Although this study could not assess the quality of midwifery education itself, the education map indicates that a wide range of training course and educational institutions of midwifery education exists worldwide. In addition, the results suggest the challenge to human resource development of SBAs in the AFRO, where countries have higher rates of both MMR and TFR.

\section{Limitations}

This study includes several limitations related to the secondary data analysis. A major disadvantage of using secondary data is that it may not control what is contained in the data set. For example, the academic degree of midwifery education did not include Doctor of Nursing Practice (DNP) or Advanced Nurse-Midwifery Practitioner. Moreover, auxiliary midwives, one of the SBAs, could not be distinguished by academic degree. Another significant disadvantage is that the researchers did not know how the data collection procedure was performed. In addition, some data appeared to be unreliable. As a result, this ICM map should be interpreted with caution.

Moreover, data from only the ICM member countries were analyzed in this study. Considering the number of United Nations member states, this study excluded data from 80 countries.

\section{Conclusion}

In this study, we intended to present an overview of global midwifery education by plotting data obtained from an ICM database on a world map. The results showed the diversity of midwifery education worldwide in terms of education level at the time of graduation, type of midwifery education, and the average number of graduates per midwifery educational institution. Direct-entry programs were adopted more than post-nursing midwifery programs. In countries with high rates of MMR and TFR, a diploma course was more likely to be provided, and the number of graduates per institution tended to be higher.

\section{Acknowledgment}

We greatly appreciate Professor Kukiko OGAWA and Lecturer Yukie IZUKA of the Tokyo Women's Medical University for supporting us revising the article. This study was conducted as a part of the activities of the International Committee (2017-2018) of the Japan Society of Midwifery Education.

\section{Conflict of Interest}

The authors have no conflicts of interest to declare.

\section{References}

Castro Lopes, S., Nove, A., Ten Hoope-Bender, P., de Bernis, L., Bokosi, M., Moyo, NT., et al. (2016). A descriptive analysis of midwifery education, regulation and association in 73 countries: the baseline for a post-2015 pathway. Human Resources for Health, 14(1), 37.

Hockley, W.E. (2008). The picture superiority effect in associative recognition. Memory \& Cognition, 36 (7), 1351-1359.

ICM (2013). Global Standards for Midwifery Education (2010). Amended 2013. Retrieved from: https://www. internationalmidwives.org/assets/files/general-files/ 2018/04/icm-standards-guidelines_ammended2013.pdf (Access: 2020.08.13)

ICM (2018). Open Data Portal for the International Confederation of Midwives Map. Retrieved from: https://icmdirectrelief.opendata.arcgis.com/datasets/icm-dataportal (Access: 2020.08.13)

ICM (2019). Essential Competencies for Midwifery Practice 2018 UPDATE. Retrieved from: https://www. internationalmidwives.org/assets/files/general-files/ 2019/02/icm-competencies_english_final_jan-2019- 
update final-web_v1.0.pdf (Access: 2020.08.13)

Ohara, R. \& Kuboda, K. (2015). The status and tasks of midwifery education at Australia: From reports about starting bachelor of midwifery education. Journal of Japan Academy of Midwifery, 29 (2), 219-229. (in Japanese)

Sannomiya, M., Sasagawa, E., Hikita, N., Yonezawa, K., \& Haruna, M. (2019). The proportions, regulations, and training plans of male midwives worldwide: a descriptive study of 77 Countries. International Journal of Childbirth, 9(1).

UNFPA, WHO, ICM (2014). The State of the World's Midwifery 2014: a universal pathway. A woman's right to health. Retrieved from: https://www.unfpa.org/sowmy (Access: 2020.8.13)

UNICEF (2019). The State of the World's Children 2019.
Children, Food and Nutrition: Growing well in a changing world. New York. Retrieved from: https://www.unicef. org/media/63016/file/SOWC-2019.pdf (Access: 2020. 8.13)

WHO (2013). Nursing and midwifery progress report 20082012. Geneva. Retrieved from: https://www.who.int/hrh/ nursing_midwifery/NursingMidwiferyProgressReport.pdf (Access: 2020.08.13)

WHO (2015). Nurses and Midwives: A Vital Resource for Health: European compendium of good practices in nursing and midwifery towards Health 2020 goals. Copenhagen. WHO Regional Office for Europe. Retrieved from: http://www.euro.who.int/_data/assets/ pdf_file/0004/287356/Nurses-midwives-Vital-ResourceHealth-Compendium.pdf?ua=1 (Access: 2020.08.13) 


\title{
マッピングによる109カ国の助産師教育の可視化： 国際助産師連盟 (ICM) データの二次分析
}

\author{
全国助産師教育協議会国際関連活動委員会 (2017年～2018年), \\ 笹川恵 美 ${ }^{* 1}$, 大田 康 江 ${ }^{* 2}$, 松 㠃 政 代 ${ }^{* 3}$, \\ 新 福 洋子*4, 大石 時 $* * 5$ \\ *1 東京大学大学院医学系研究科 \\ $* 2$ 順天堂大学大学院医療看護学研究科 \\ $* 3$ 大阪大学大学院医学系研究科 \\ $* 4$ 広島大学大学院医系科学研究科 \\ *5 高崎健康福祉大学
}

\section{抄 録}

\section{目 的}

本研究は，国際助産師連盟 (International Confederation of Midwives：ICM)のデータに含まれる指標 のうち，助産師教育に関する項目を分析し，世界の助産師教育の可視化を通じ，その現状と多様性の理 解促進を目的としている。

方 法

ICMのウェブサイトから，入手可能なデー夕113カ国中，109力国のデー夕を用いて二次分析を行つ た。具体的には，(1) 助産師教育卒業時の学位，(2) 助産師教育の課程，(3) 助産師教育施設毎の卒業生 数を分析し，結果を世界地図上にマッピングして可視化した。結果は，世界保健機関 (World Health Organization：WHO) の区分による6地域 (アフリカ, 米州, 南東アジア, 欧州, 東地中海, 西太平洋地 域)で比較した。

\section{結 果}

助産師教育卒業時の学位は，有効データがある 87 国を分析した。高等専門学校課程修了による助 産師資格は47力国 (54.0\%)，学士は65力国 (74.7\%)，修士は35力国 (40.2\%) が有していた(複数回答)。 助産師教育の課程を 94 カ国について調べた結果，ダイレクトエントリー課程を採用しているのは 76 力 国 (80.9\%)，看護教育後の助産師教育課程を採用しているのは57カ国 $(60.6 \%)$ であり，修行期間の平均 は，それぞれ36力月，19.4カ月だった。助産師教育施設毎の卒業生数は，80カ国のデー夕を分析し，年 間卒業生の中央値は 22.5 人であった。

結 論

ICMデー夕を基にした世界地図は，世界の助産師教育課程と助産師教育機関の多様性を示した。世界 では，助産師教育にダイレクトエントリー課程を採用している国が多いことが明らかとなった。妊産婦 死亡率や合計特殊出生率が高いアフリカ地域の国では，高等専門学校課程による助産師育成が多く，1 施設毎の助産学生の数は増加する傾向が示唆された。

キーワード：助産師，教育，国際助産師連盟，世界保健機関 